\begin{tabular}{|c|c|c|c|c|c|c|}
\hline \multirow{4}{*}{ Impact Factor: } & ISRA (India) & $=3.117$ & SIS (USA) & $=0.912$ & ICV (Poland) & $=6.630$ \\
\hline & ISI (Dubai, UAE & $=0.829$ & РИНЦ (Russia) & $=0.156$ & PIF (India) & $=1.940$ \\
\hline & GIF (Australia) & $=0.564$ & ESJI $(\mathrm{KZ})$ & $=8.716$ & IBI (India) & $=4.260$ \\
\hline & JIF & $=1.500$ & SJIF (Morocco) & $=5.667$ & OAJI (USA) & $=0.350$ \\
\hline
\end{tabular}

\begin{tabular}{|c|c|}
\hline $\begin{array}{l}\text { SOI: } \frac{1.1 / \mathrm{TA}}{\text { International Sc }} \\
\text { Theoretical \& A }\end{array}$ & $\begin{array}{l}\text { IS DOI: } 10.15863 / \mathrm{TAS} \\
\text { cientific Journal } \\
\text { aplied Science }\end{array}$ \\
\hline p-ISSN: 2308-4944 (print) & e-ISSN: 2409-0085 (online) \\
\hline Year: $2019 \quad$ Issue: 06 & Volume: 74 \\
\hline Published: 30.06 .2019 & http://T-Science.org \\
\hline
\end{tabular}

SECTION 13. Geography. History. Oceanology. Meteorology.
QR - Issue

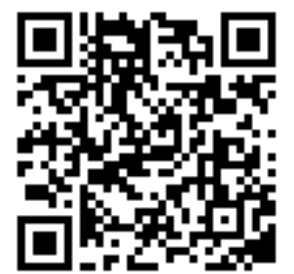

QR - Article

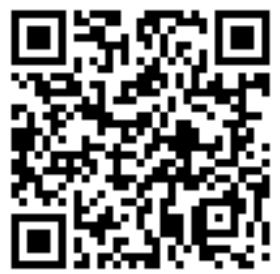

T.U. Salimov

National University of Uzbekistan

Associate professor,

Tashkent, Republic of Uzbekistan

\title{
ECONOMIC AND CULTURAL TRADITIONS OF THE POPULATION OF THE NURATA MOUNTAINS AND ADJUSTING TERRITORY: IN THE PAST AND PRESENT
}

Abstract: This article analyzes geographical position, population of Nurata Mountains and their economical and cultural traditions based on archive sources and scientific literatures. Statistical materials are analyzed in this article.

Key words: Nurata Mountains, society, economy, economical life, irrigated farming, collective farms, ethnographic research.

Language: English

Citation: Salimov, T. U. (2019). Economic and cultural traditions of the population of the Nurata mountains and adjusting territory: in the past and present. ISJ Theoretical \& Applied Science, 06 (74), 566-569.

Soi: http://s-o-i.org/1.1/TAS-06-74-69 Doi: crosłef https://dx.doi.org/10.15863/TAS.2019.06.74.69

\section{Introduction}

The Nurata mountains covered the territory of the ancient Sogd and the Bukhara oasis with the hot Kyzylkum sands. In the distant past, access to the Zeravshan valley was possible only through the Ilanutta mountain gorge (because of the winding road, it was compared to the serpent track) at Dzhizak and Nurata as the most important points were protected by fortress walls [1].

The northern slopes of the Nurata mountain range facing the endless expanses of the Kyzyl Kum region abound in numerous mountain streams along which spring waters flow. Thanks to the latter, in the gorges and in front of them there were settlements, whose inhabitants are engaged in farming and animal husbandry. Uzbeks live in the gorges located to the south-east of Jizzakh to the center of Farish district of Yangikishlak, and to the west of it to Nurata live Tajiks. They are engaged in farming and partly animal husbandry, their lifestyle is mostly similar. The villages are located on the slopes of the main Saya, inside the gorge. Dwellings are built of stone and beams [2].

15-20 km north of the foothills of the Nurata mountains, parallel to it is a large ancient steppe road connecting Bukhara through the Nurata with the regions of South Kazakhstan, Semirechiy, etc. At one time, there was a ferry on Syrdarya near Chardara.
From there the path to the west lay across the steppe. For each approximately $30 \mathrm{~km}$, a fortified rabat with a well was built. The ruins of these shops remained until the middle of the XX century. Nurata is an extreme city in the north of the Bukhara (now Navoi) region, from there to the north and northeast to the lower reaches of the Syr Darya, steppes and sands of the Kyzyl Kum region extend. Until the beginning of the twentieth century, Nurata was a frontier trade and craft town with a fortress, where the Bek, a protege of the Emir of Bukhara, was located.

\section{Materials and methods}

Under a treaty of 1868, Russia and the emir of the Bukhara steppes of the northern part of the Nurata Mountains were transferred to the Russians. According to the head of the Jizzakh district, in all the villages of the Bogdanatins volost can be combined up to 1300 inches [3]. Owing to the unfavorable conditions of the area, the population of the northern slope of the mountains, which does not allow widespread development of agriculture, can be called far from rich. Insignificant crops and not particularly high yields do not satisfy the needs of the population and, as a result, they are forced to seek support for cattle breeding, which, nevertheless, is not particularly developed, materially unsatisfied Uzbeks of the Nurata Mountains are far behind culturally as 


\begin{tabular}{|c|c|c|c|c|c|c|}
\hline \multirow{4}{*}{ Impact Factor: } & ISRA (India) & $=3.117$ & SIS (USA) & $=0.912$ & ICV (Poland) & $=6.630$ \\
\hline & ISI (Dubai, UAI & $=0.829$ & РИНЦ (Russia & $=0.156$ & PIF (India) & $=1.940$ \\
\hline & GIF (Australia) & $=0.564$ & ESJI (KZ) & $=8.716$ & IBI (India) & $=4.260$ \\
\hline & JIF & $=1.500$ & SJIF (Morocce & $=5.667$ & OAJI (USA) & $=0.350$ \\
\hline
\end{tabular}

well. Of the inhabitants of the Bogdanatinsvolost, only those who have gardens and irrigated lands are firmly confined to the place, the rest are almost always in absenteeism, seeking earnings in Miankale.

Sintab, Ustuk, Temirkauk, Turkmen rural communities are located in the northern part of the Nurata mountains. If the population of the Kyzyl Kum region was mainly engaged in cattle breeding and only partially sowed grain on non-irrigated lands under natural rainfall, the residents of mountain villages, on the contrary, mainly engaged in irrigated and nonirrigated farming, and their cattle breeding had an auxiliary character.

Table 1 shows the economic census. The population of 13 villages in the late XIX-early XX centuries. So from the table it can be seen that out of 486 farms of the village, only 326 have land plots, the number of landless 160 farms. These farms have 88 horses, 180 bulls, 140 cows, 186 donkeys, 4000 heads of cattle. In the villages of Mozhirim and Andagon there are 382 farms, including landowners 269, 113 landless, 30 horses, 64 bulls, 20 cows, 120 donkeys, 2600 small cattle.

If we analyze in general, the number of landless farms is from $20 \%$ to $30 \%$, horses 1 for every 5 farms, bulls for 3 farms, even fewer cows, small-sized cattle, on average, less than 10 farms per farm. At the same time, in the villages there were also rich, average people, meaning a very large number of farms did not have not only land, but also domestic animals. In the villages of Sof and Temirkauk, the situation was even worse; about half of their farms did not have their own land plots.

Prior to the establishment of Soviet power, the lifestyle of the three groups of people in the Nurata mountain-Tajiks, the Uzbeks-Turkman highlands and the Uzbeks-Turkman Dzhadir had differences related to the existing climatic conditions.

The Tajiks were mainly engaged in irrigated farming, on the irrigated lands they sowed only prosperous peasants who had a sufficient number of animals [4]. The irrigated lands were divided: 1) location in the gorge and its slopes, and 2) loika located in the piedmont zone. On the lands of the first species were grown: here, walnuts, fruit trees, garden crops and alfalfa, in the lower part of the gorge, there were also crops of Asian cotton-Guza. Fruits (apricots, peaches, apples, jida, figs) were consumed not only fresh but also dried. Talcon (sweet flour) was made from dried mulberries and apples. Sugar varieties of mulberries went to boil-Kiyom, a type of jam.

In the lands of the second type, the Tajiks grew grains, oilseeds and melons, and cotton. These lands were located at a distance of $5 \mathrm{~km}$ or more, where the piedmont plain descending from the mountains, which is a stony steppe with semi-desert vegetation, merges with the desert. Here on a flat plain, where the water of mudflows, rushing from the mountains during the spring tides and with the intensified melting of snow, spreading evenly, flooded its entire surface as such. Unlike takyr, as the water gradually absorbs into the soil and partially evaporates it, the earth does not become covered with a hard crust and does not crack, as this is prevented by the finest fine sand contained in fertile silt brought by mudslides and settling in the fields [5].

The plane flooded by mud of mudflows was called loika-silt. It can be said that the kukpoy or loika-il is one of the varieties of estuary irrigation. In order for the mudslide not to go far into the sand (as it flows but to a shallow rocky bed) and spread over the fields, beforehand, immediately after completion of sowing (sowed in February-March), a dam (gangs) of stone were erected on a dry bed, camel spines and other dried herbs last year.

The dam was constructed not across sai, i.e. not at a right angle (so that he did not pick it up), but obliquely, at an acute angle towards the irrigated field. In the past, several villagers (up to 10 people) built a dam together.

Sowing ten poods of seeds of various crops: wheat, barley, millet, flax and sesame was common for the average farmer who had a couple of oxen.

Wheat yielded the greatest yield of up to 8 centners. According to informer O. Rajabova [6], cotton and melons were also grown there. The area intended for melons was usually watered in the autumn-winter period when, after falling rain and snow, the water in the mountainous rivers arrived and sometimes reached the harbor. This water was allowed on a plot that was plowed once. The soil was so saturated with moisture that melons and watermelons sown in spring had abundant fruit without watering [10]. Melons sunk into the sun (they were hung up by cutting into long slices and removing the crust with a knife) were a tangible help in the nutrition of the population in the winter-spring period [7].

The short winter and the availability of seasonal pastures made it possible for the sedentary population to engage in livestock farming other than farming. A middle-income villager usually had two working oxen, a horse, a donkey, two or three cows and a dozen or a little more sheep and goats. The cattle were kept in the stall only in winter, on snowy days, for a total of 2-3 months. Only cattle and horses received lure. From March to May, the inhabitants of the mountain villages migrated along with the cattle to the steppe to the piedmont hills and the piedmont plain. On spring pastures, women were engaged in harvesting dairy products for rent. During the field ethnographic research, we learned that the cattle of the population of the village of Sintab is still in the summer pastures in the mountain pastures around Lake Fazilman and the women of the village several people take turns going to the mountains to prepare butter for the winter. All summer and most of the autumn, the population lived in gardens, and cattle grazed in the mountains. 


\begin{tabular}{|c|c|c|c|c|c|c|}
\hline \multirow{4}{*}{ Impact Factor: } & ISRA (India) & $=3.117$ & SIS (USA) & $=0.912$ & ICV (Poland) & $=6.630$ \\
\hline & ISI (Dubai, UAI & $=0.829$ & РИНЦ (Russia & $=0.156$ & PIF (India) & $=1.940$ \\
\hline & GIF (Australia) & $=0.564$ & ESJI (KZ) & $=8.716$ & IBI (India) & $=4.260$ \\
\hline & JIF & $=1.500$ & SJIF (Morocco & $=5.667$ & OAJI (USA) & $=0.350$ \\
\hline
\end{tabular}

Until the beginning of the 20th century, people lived in the village only in winter.

The subsidiary occupations of residents of all the villages of the northern part of the Nuratau Mountains were spinning cotton threads, on manual spinning and weaving on machines with pedals. Spinning was a feminine matter, and weaving was masculine. According to the recollections of Tajik residents, and in some cases, Uzbeks continued to engage in weaving until the middle of the twentieth century [8]. The missing cotton was acquired at the bazaars in Kattakurgan and Khatirchi. Each village had its own blacksmiths, carpenters, shoemakers, and parikhmakhery. Some masters owned several specialties that is an indicator of the weak development of rural crafts.

Cattle breeding is the basis of the UzbekTurkmen economy of the Nurata Mountains. In the archival materials of the $70 \mathrm{~s}$ of the nineteenth centuries. there is such data. In the south-west of the Temirkauk kishlak in the mountains are a small number of Uzbek-Turkmen about 200 houses. They are semi-settled people, their main occupation is cattle breeding and only the excellent quality of land on the eastern slopes and in rainy years significant yields cause them to tillage. Most Uzbek-Turkmen live in yurts all year round and feed their sheep in the steppe, where they have their own wells. Western Turkmen, as well as to the north of the mountains in the direction of the Syr Darya, begins a purely nomadic population consisting of Kirghiz (Cossacks) and Karakalpak [9].

The basis of the Uzbek-Turkmen Highlands and Jadir economy was non-irrigated agriculture and cattle breeding. The proper representatives of the UzbekTurkmens of the highlands also had land on the harbor. Grain, oilseeds and melons were grown there. Small plots of irrigated land and springs occupied exclusively for alfalfa, which was the main feed for horses.

Following the sowing in March, UzbekTurkmen migrated with livestock to the steppe. In the piedmont hills were special tracts where sheep lambing occurred. The Kazakh breed of sheep was bred for wool and meat, only a few bais of jadirs in the early twentieth century had ateye of astrakhan sheep. In dry years, cattle were kept in the sands near wells located $20-30 \mathrm{~km}$ from the villages. In June, after harvesting from the fields, they returned to the villages, where cattle were grazing along stubble and on mountain pastures. The considered groups of Uzbeks-Turkmen were bred: sheep, goats, cattle, horses, donkeys and camels. The Jadirs who had little land suitable for agriculture had more camels and less cattle compared to the highland Turkmen. These groups, in contrast to the Temirkauks, the only type of dwelling was a trellised yurt, covered with felt. Permanent premises (made of clay-bonded stone) were erected only for horses and for the storage of fuel.
We can assume that until the beginning of the twentieth century, the economy and way of life of the Uzbeks, the Turkmen of the north-western tip of the Nuratau Mountains, were typical of the semi-nomadic Uzbeks.

The economic and cultural types of the population of the Nurata oasis in the twentieth century endured a number of significant changes. So with the establishment of Soviet power, the land and property of rich people were confiscated by the 1930s, collective farms were formed, and they gradually included almost all of the population, except for the dispossessed middle peasants and the rich. During the war, the population employed in the collective farms grew not only grain but also cotton. According to informants, cotton was grown on grass.

At the end of the $50 \mathrm{~s}$, a transformation began in the management system and on the site of low-power collective farms, large karakul-breeding state farms were created. They began to provide transport: tractors, trucks, cars. Sheep herding flocks were shepherds, grain crops were grown on irrigated land, and in rainy years, 10-15 centners per hectare of good yields were obtained.

It should be noted that the living standards of the majority of the population increased. The whole population was covered by education, hospitals and other cultural institutions were built in large villages and in the city of Nurata. At the same time, cases that led to the violation of traditional economic and cultural types have become frequent. With the formation of state farms (state farms), loika were abandoned, karezes (each of which irrigated several hectares of land). The population basically lived at the expense of their gardens and livestock. They began to grow the grape "hatirchi uchkorasi" without the stone dried them and the raisins were sold on the markets of close and distant cities. As a result, this type of raisin (dried grapes) is still highly valued by lovers of this type of dried fruit. To this day, in the Nurata oasis, the main income items are raisins, fruits, vegetable crops and domestic animals: cattle, sheep breeding. If in the Tadzhik villages of the north of the Nurata mountains the agricultural products of agriculture prevail in incomes, then among the former semi-nomads the main part of family expenses is covered by sheep farming.

\section{Conclusion}

Over the past 2-3 years in Uzbekistan, including in the Nurata district, they began to develop the foothill strip adjacent to the desert in order to grow walnuts, pistachios and other fruit trees on these lands. To water these lands water is extracted by electric pumps. The state provides farmers with loans on a long-term and medium-term basis. Who knows it will take several years and the once vacant land where grazing cattle will probably become beautiful gardens. By the way, those state farms that were engaged in 


\begin{tabular}{|c|c|c|c|c|c|c|}
\hline \multirow{4}{*}{ Impact Factor: } & ISRA (India) & $=3.117$ & SIS (USA) & $=0.912$ & ICV (Poland) & $=6.630$ \\
\hline & ISI (Dubai, UAI & $=0.829$ & РИНЦ (Russia & $=0.156$ & PIF (India) & $=1.940$ \\
\hline & GIF (Australia) & $=0.564$ & ESJI (KZ) & $=8.716$ & IBI (India) & $=4.260$ \\
\hline & JIF & $=1.500$ & SJIF (Morocco & $=5.667$ & OAJI (USA) & $=0.350$ \\
\hline
\end{tabular}

karakul have sunk into history. With the collapse of the former Soviet Union and the beginning of the transition to market relations, they gradually disbanded.

The main problem that traditionally remains for the mountain population is unemployment. Young men travel to the city, sometimes to the CIS countries in search of work and decent earnings. This trend will continue for some time until the construction of industrial facilities in rural areas, including the Nurata district, is imposed.

\section{References:}

1. (1991). Polevye materialy avtora.

2. Gulyamov, Y. G. (1979). Nur Bukharskiy. Etnografiya $i$ arkheologiya Sredney Azii. (p.133). Moscow: Nauka.

3. (1971). TsGA RUz. I.1, op. 22, d. 15, 1869-1873 gg. Raport nachal'nika Syrdar'inskoy oblasti ob osmotre zapadnoy chasti Dzhizakskogo uezda i naseleniya Kyzylkuma i perepiska po voprosu ob ustroystve kirgizov(kazakhov) na obshchikh, s prochim naseleniem osnovaniyakh. Raport ot 12 yanv. 1871 goda.

4. Khoroshkhin, A. P. (1876). Kyzylkumskiy dnevnik. V pn. Khoroshkin A.P . Sbornik statey, kasayushchikhsya do Turkestanskogo kraya SPb, pp. 398-402.

5. Karmysheva, B. K., \& Peshcherova, E. M. (1964). Materialy etnograficheskogo obsledovaniya tadzhikov Nuratinskogo khrebta. SE., №1, pp.10-11.

6. Mukhammadzhanov, A. R. (1968). Kadimgi suv inshootlari tarikhidan. (p.6). Tashkent.

7. (1991). Materialy polevykh issledovanii k. Katta Ezh.

8. Khoroshkin, A. P. (n.d.). Kyzylkumskiy dnevnik. p. 407.

9. (1991). Polevye zapisi avtora k. Sintab.

10. (1871). I.f. 1 op 22, do 15, 1869-1973 gg. Raport nach. Syrdar'inskoy oblasti ot 12 yanv. $1871 \mathrm{~g}$.

11. Karmysheva, B. K. (1976). Novye materialy po naseleniyu Nuratinskogo khrebta. Polevye issledovaniya Instituta etnografii AN SSSR. (pp.142-158). Moscow. 